\title{
CORONAVIRUS (COVID-19): A NEW ERA FOR ONLINE EDUCATION?
}

\author{
Angie Parker \\ Dr., American College of Education, U.S.A. angie.parker@ace.edu
}

\begin{abstract}
The Coronavirus has disrupted life in the United States as well as around the globe. Businesses, economics, and even education have been at the epicenter of this pandemic. This research is centered around 412 university students who are also K-12 teachers in seven countries. The research focuses on the changing needs of these online students from before the pandemic to the days when the quarantines disrupted life as we know it. Drawing on current literature, this study seeks answers related to how today's adult learners want to learn and how that learning will undoubted be changed. The eight-question survey identifies evolving trends in the online classroom. The utilization of interaction and a sense of presence in online learning has in the past been essential to engagement. Much research has also focused on interaction and retention. During and following social distancing and quarantine, the wheels of education were turning to accommodate new learning methodologies and new shifts in interaction. This study then explored how interaction will evolve in the months and years to come. Subsequently the study considers at the impact of the Coronavirus on education today, and how the role of the educator is being altered. Finally, the study addresses the potential for reopening schools and how that process will impact distance learning.
\end{abstract}

Keywords: Coronavirus, education, adult learning needs, K-12 education, distance education

\section{INTRODUCTION}

Distance education is not new to the world of learning, but how distance education has changed due to Coronavirus (COVID-19 is. How has the recent global pandemic changed the outlook for all of education? This study looks at the results of a survey given to college students prior to the pandemic and again during the height of the quarantines and the onset of virtual schools for nearly all of the world. The students $(n=412)$ were K-12 teachers in seven countries. The survey focused on their needs as virtual students and specific interactions they anticipated from their professors. The results show very different learning needs as well as redefined expectations in their interactions with their professors.

\section{REVIEW OF THE LITERATURE}

Distance education provides students with academic opportunities they might otherwise be unable to obtain within a local, standard classroom. Educational theorists grapple with the goals, unique advantages and disadvantages of distance education. While long distance correspondence courses have existed for generations, distance education theory is a relatively new field of scholarship triggered by recent advances in telecommunications technology enabling the mass delivery of education through online courses ( Trayler, 2018),

The three contemporary founders of distance education theory are Otto Peters (1994), Borje Holmberg (1997) and Michael G. Moore (1973). During the 1990's, Otto Peters (1994) proposed an industrialization theory to explain the proliferation of distance education options. Several years later, Holmberg proposed the 
theory of didactic interaction to describe the differences between synchronous and asynchronous. Moore (1973) then proposed a relationship between teacher-student interactions and structures. He argued that a greater quantity and quality of interaction enabled students and teachers to overcome structural barriers such as space and time.

Distance education in 2020 has a totally new focus and utilization of interaction (Liao, 2017). Today that interaction can be done totally at a distance (Lanham, 2017). The availability of tools like Skype, Zoom, and Google, have made possible interaction not only in the classroom or school district but around the globe. In the classrooms of early 2020 , interaction was seen as students collaborating on problem-based learning projects. The use of tools like Skype were readily available but not prominent in the learning.

In a recent article in Forbes (Busteed, 2020) the author states that as much as we'd all like to reopen schools and universities for this coming academic year, there are serious ramification never before dealt with in educational circles. The article continues by looking at the motivation throughout the world to reopen schools - students need school support services like free and reduced lunch, providing adequate Internet and device for students without access at home, to assist parents whose work is dependent on school as childcare, and for all everyone who craves some return to normalcy.

As educators, the truth is evident that the version of school students will most likely return to won't be anything like it was before (Busteed, 2020). The interaction with students had grossly changed as well. With all the required protocols and considerations for social distancing during a global pandemic, education will be totally reshaped.

These changes have also impacted the teachers who suddenly have been thrust into a totally new era of education. They have never been trained to revise daily lessons nor to teach virtually. The hours of time required has now doubled as preparation takes twice the material, twice the thought, and twice the need to find ways to integrate "never before used" technologies. Additionally, the reopening of schools brings school districts into a new era of legal matters (Gan \& Balakrishman, 2018). School administrators see evolving and unprecedented legal liability considerations for schools and universities (Boyd, 2020). What will be considered a reasonable standard for a school or university to prevent the spread of COVID-19? Will the efforts described above be enough to protect schools from lawsuits in the event students, staff or teachers become ill (Boyd, 2020)? What about the protection of student and employee private health information such as their COVID-19 test results or temperature check station results?

\section{METHODOLOGY}

This study collected data from 412 teachers who were enrolled in a Master's Level Educational Technology program. The survey was given in early January 2020 and again in April, 2020. All of the teachers taught initially in traditional K-12 classrooms in seven countries. The students volunteered to complete an 8question survey asking for their expectations as full-time teachers and their learning needs as university students. The results of the two surveys both prior to the upstart of the pandemic and during the height of quarantine, indicated totally different expectations. The following sections of this research study will illustrate the expectation before and during the pandemic. Brief comments to some survey questions allowed more indepth analysis of why the outcomes varied widely.

\section{Survey and analysis before and during Coronavirus pandemic}

The following section of this study will provide not only the actual survey questions but an analysis of the results. If students added comments, those too will be discussed.

Question one (Table One) delves into the need for interaction between the student and the online professor. In the first survey, the need for interaction was seen as essential. Perhaps a way to enhance the quality of the learning beyond the material presented in lectures and readings. The results of the second survey were considerably different as the same students had limited time to interact beyond what was the minimal requirements. The advent of virtual teaching had changed the time and the propensity for their own online learning. The use of added interaction is now seen as unnecessary and time consuming.

Table One: Survey Question One

\begin{tabular}{|l|l|l|}
\hline $\begin{array}{l}\text { What methods should your professor use to use to interact } \\
\text { with you personally during the course? }\end{array}$ & & \\
\hline & January, & April, 2020 \\
\hline Comments on all assignments & $\mathrm{n}=400$ & $\mathrm{n}=396$ \\
\hline
\end{tabular}


Proceedings of SOCIOINT 2020- 7th International Conference on Education and Education of Social Sciences, 15-17 June 2020

\begin{tabular}{|l|l|l|}
\hline Interaction with discussions & $\mathrm{n}=398$ & $\mathrm{n}=327$ \\
\hline Individual and group emails & $\mathrm{n}=390$ & $\mathrm{n}=107$ \\
\hline Conferencing i.e. Zoom or Skype & $\mathrm{n}=380$ & $\mathrm{n}=94$ \\
\hline
\end{tabular}

The next question in the survey (Table Two) addressed the students' need for quick information within the course. Announcements are generally brief and address a single pertinent issue within the course structure. The changes in this question were not as defined as in other examples. The students, even in the pandemic times, relied on quick information. One teacher suggested that the announcements were the "life line" of the course...quick and to the point.

Table Two: Survey Question Two

\begin{tabular}{|l|l|l|}
\hline How often do you read the Announcements? & & \\
\hline & & \\
\hline Daily & January, 2020 & April, 2020 \\
\hline Weekly & $\mathrm{n}=397$ & $\mathrm{n}=187$ \\
\hline Only when I need information & $\mathrm{n}=12$ & $\mathrm{n}=186$ \\
\hline
\end{tabular}

The discussion in nearly all online classes provides interaction and the opportunity to learn from a variety of peers. The third table, (Table Three) focused on the discussion. In many online courses, the discussion is the interaction scenario. It is where the majority of the students share ideas, receive new viewpoints both from their peers and from the professor. The concept of peer learning recognizes that students are an important source of knowledge in addition to faculty and course material (Lanham, (2017) Students are not passive receptacles to be filled with information, instead, they are active learners. Being a member of a learning community means engaging in reciprocal learning activities, soaking in new ideas and sharing perspectives and experiences to make meaning of the information (Boud, 2020) Learning happens through discussion, reflection, collaborative teamwork, and most importantly, taking initiative and responsibility to listen, question, and think critically within the community of fellow learners.

Table Three: Survey Question Three

\begin{tabular}{|l|l|l|}
\hline $\begin{array}{l}\text { How important is interacting with your professor } \\
\text { in the discussion? }\end{array}$ & & \\
\hline & January, 2020 & April, 2020 \\
\hline Important, I gain new information from the professor. & $\mathrm{n}=389$ & $\mathrm{n}=215$ \\
\hline Somewhat, I like reading the ideas of other students & $\mathrm{n}=12$ & $\mathrm{n}=167$ \\
\hline Not important & $\mathrm{n}=3$ & $\mathrm{n}=30$ \\
\hline
\end{tabular}

Students in the class originally enjoyed the interaction between faculty and student (Table Four) questions the need for interaction. It is evident that before and during the pandemic students still had a healthy respect to the interaction with the course professor. The numbers dwindled as the pandemic and the need for the teachers to transition to a new role in their own teaching and learning. Virtual interaction allows students to receive affirmation about their own ideas. Most recently, with the pandemic, that interaction has been changed to focus solely on the need for immediate feedback. Learning happens through discussion, reflection, collaborative teamwork, and most importantly, taking initiative and responsibility to listen, question, and think critically within the community of fellow learners and the professor. Teachers who are already stressed with online lesson planning and delivery see the need for more $Q$ \& $A$ and less lengthy interaction.

Table Four: Survey Question Four

\begin{tabular}{|l|l|l|}
\hline How often do you interact with your professor one-on-one? & & \\
\hline & January, 2020 & April, 2020 \\
\hline Daily & $\mathrm{n}=317$ & $\mathrm{n}=2$ \\
\hline B-weekly & $\mathrm{n}=30$ & $\mathrm{n}=17$ \\
\hline Weekly & $\mathrm{n}=9$ & $\mathrm{n}=322$ \\
\hline Only if I need to & $\mathrm{n}=2$ & $\mathrm{n}=71$ \\
\hline
\end{tabular}


Online students often interact individual with their instructor. They ask questions and provide material to verify their own learning. This table (Table Five) identified the media used for this interaction. The table illustrates the change in available time and interest in interaction. In the beginning students were willing to participate in added interaction and conferences to provide not only $Q$ \& $A$, but to expand on the information in the course. Interaction in online learning instructional interaction is meaningful communication that challenges learners' thinking, shapes the acquisition of knowledge in meaningful ways, and changes learners, moving them toward achieving their goals (Liao, 2017) Keeping students engaged can be particularly challenging in online learning — not just when it comes to course material, but in making students feel like part of an institutional community.

This question also addressed social media in an effort to determine if students were willing to utilize this media. Social learning is active learning, which means that students participate directly in their own learning (Daniel, 2019). The results show that prior to the quarantines, the students were somewhat more willing to take the extra time to utilize social media.

Table Five: Survey Question Five

\begin{tabular}{|l|l|l|}
\hline $\begin{array}{l}\text { What media do you use most often to interact with your } \\
\text { professor? }\end{array}$ & & \\
\hline & January, 2020 & April, 2020 \\
\hline Discussion in the course (Graded) & $\mathrm{n}=317$ & $\mathrm{n}=395$ \\
\hline Course communication tools & $\mathrm{n}=20$ & $\mathrm{n}=10$ \\
\hline Social media & $\mathrm{n}=16$ & $\mathrm{n}=5$ \\
\hline Zoom or a similar tool & $\mathrm{n}=5$ & $\mathrm{n}=2$ \\
\hline
\end{tabular}

The survey next identified the interest student have in the research agenda of their professors (Table Six). Often students realize those articles or research agendas can be of use in learning. This question asked if the availability of the professor's research was of interest in their own learning. In a recent article by Daniel (2019) it was evident that students who became familiar with the research of their instructors learned not only the process of research, but the methodology for constructing similar project on their own. Although the initial survey and the second edition were very different is was evident that students during quarantine were not ready to indulge in the reading of extra, high level research.

Table Six: Survey Question Six

\begin{tabular}{|l|l|l|}
\hline Do you want access to the research of your professor? & & \\
\hline & January, 2020 & April, 2020 \\
\hline Yes & $\mathrm{n}=365$ & $\mathrm{n}=52$ \\
\hline Maybe if it pertains to the course material & $\mathrm{n}=32$ & $\mathrm{n}=255$ \\
\hline No & $\mathrm{n}=15$ & $\mathrm{n}=105$ \\
\hline
\end{tabular}

Question Seven (Table Seven) This query was seeking information on the additional materials that potentially could augment the course material. This question had a wide difference between the first and second survey. Prior to the pandemic and virtual teaching, the students enjoyed the diversion with new tools to "play with" and new ideas to explore. Following the pandemic, students suggested they lacked the time to explore new tools but instead wanted quick ideas to add to their own online teaching. Many asked for new resources to create quick videos or audio files. Games with a high level of educational value were also often requested.

Table Seven: Survey Question Seven

\begin{tabular}{|l|l|l|}
\hline $\begin{array}{l}\text { Should your professor provide extra readings, websites, } \\
\text { and material to enhance the course? }\end{array}$ & \\
\hline & January, 2020 & April, 2020 \\
\hline Yes & $\mathrm{n}=382$ & $\mathrm{n}=19$ \\
\hline Maybe if I can use it to learn more about the topic & $\mathrm{n}=27$ & $\mathrm{n}=92$ \\
\hline No & $\mathrm{n}=3$ & $\mathrm{n}=301$ \\
\hline
\end{tabular}


Finally, question eight (Table Eight) looked at the use of conferencing as an interaction tool within an online classroom. In the initial survey, students suggested they would like to try a conference call but wanted to assure it was at a convenient time for them. They indicated a need to adhere to asynchronous interaction techniques and the interaction needed to be limited. Half of the students suggested using conferencing monthly or not at all. Even stronger results are seen in the second survey. The immediacy of information was essential, but the results indicate conferencing as lacking potential in these stressful times.

Table Eight: Survey Question Eight

\begin{tabular}{|l|l|l|}
\hline $\begin{array}{l}\text { How often would you use tools like Zoom or Skype to } \\
\text { interact with your professor or other students? }\end{array}$ & \\
\hline & January, 2020 & April, 2020 \\
\hline Once a week & $\mathrm{n}=215$ & $\mathrm{n}=10$ \\
\hline Monthly & $\mathrm{n}=97$ & $\mathrm{n}=92$ \\
\hline Never & $\mathrm{n}=100$ & $\mathrm{n}=310$ \\
\hline
\end{tabular}

\section{RESULTS}

From the results of this short survey, it becomes evident that changes in what student want and need have changed. The traditional teacher who enjoyed interacting with fellow peers in a college course, has changed focus. Added readings to enhance the material from the course is no longer a luxury to be enjoyed at the end of a day of teaching. One teacher said, "My day never ends" I have students with questions far after 10pm.". The teachers also commented that they are having to learn the new technologies to transfer learning to their students across the community. Another teacher related that her students do not all have Internet access and technology at home. Therefore, she is making paper packets of the work and has set up a "drive through" at the school where parents can pick up the work and deliver the finished assignments.

These new tasks have cut the time the teachers have for their own learning. Schools have changed and along with that change has come a change in the lives of today's educators. With 1.5 billion students out of school and hundreds of millions attempting to learn solely online, the pandemic will undoubtedly reshape schools, the idea of education, and what learning looks like in the 21st century (Artino \& McCoach, 2020). The pandemic is forcing educators, parents, and students to think critically, problem-solve, be creative, communicate, collaborate and be agile. The new way is time-consuming and strange.

In a matter of weeks, Coronavirus (COVID-19) has changed how students are educated around the world. Those changes give us a glimpse at how education and interaction within education could change for the better - and the worse - in the long term. The pandemic is giving technology massive insights as to what teaching, learning and interaction look like. This glimpse into the decades ahead shows technology as augmenting relationships with teachers, personalization, and independence. But the way the augmented interaction has been rolled out-overnight, with no training, and often in-sufficient bandwidth—will leave many with a sour taste about the whole exercise. Many teachers and students may well continue to associate e-learning with lockdowns, recalling frustrations with trying to log on, or mucking through products that didn't make sense.

This research has shown how in a few months, the direction of all education has changed and most likely will continue to evolve in new ways. Need for immediate feedback will rule the focus. Interaction with new tools will need to be carefully assessed.

\section{REFERENCE LIST}

Artino, A. \& McCoach, D. (2020). Development and initial validation of the online learning value and selfefficacy scale. Journal of Educational Computing Research, 38, 279-303. doi:10.2190/EC.38.3.c

Boud, D. (2020). Introduction: Making the move to peer learning. In D. Boud, R. Cohen, \& J.Sampson (eds.), Peer Learning in Higher Education: Learning From \& With Each Other. Sterling, VA: Stylus Publishing, Inc.

Boyd, D. (2020). The new legalities of learning. New Horizons in Adult Education and Human Resource 
Development, 18, 31-39. doi:10.1002/nha3.10184

BUSTEED, B (2020). SCHOOLS MUST BOTH REOPEN AND CONTINUE ONLINE FORBES, ONLINE RETRIEVED FROM HTTPS:/MWW.FORBES.COM/SITES/BRANDONBUSTEED/2020/05/05/SCHOOLS-MUST-BOTHRE-OPEN-AND-CONTINUE-ONLINE/\#66DDCDB945D9

Daniel, J., (2019). Education across space and time, Keynote address ODLAA summit on 04 February 2013, viewed 12 July 2013, from www.odlaasummit.org.au/keynote-speakers.php.

Gan, C. L. \& Balakrishnan, V. (2018). Mobile technology in the classroom: What drives student-lecturer interactions? International Journal of Human-Computer Interaction, 34(7), 667-679.

Holmberg, B. (1997). Distance education theory again. Open Learning, 12(1), 31-39

Lanham, R. A. (2017). The audit of virtuality: Universities in the attention economy. In S. Brint (ed.),The Future of the City of Intellect: The Changing American University(pp. 159-180). Stanford, CA: Stanford UP

Lee, Y., Driscoll, M. P., \& Nelson, D. W. (2017). The past, present, and future of research in distance education American Journal of Distance Education, 18(4), 225-241. [27]

Liao, Y.-K. C. (2017). Effects of hypermedia on students'achievement: A meta-analysis.

Journal of Educational Multimedia and Hypermedia, 8(3), 255-277.

Moore, M. (1973). Toward a theory of independent learning and teaching, Journal of Higher Education, 44, 661-679.

Peters, O. (1994). Distance education and industrial production: A comparative interpretation in ouline (1967). In D. Keegan (Ed.), The industrialization of teaching and learning (pp. 107-127). London: Routledge.

Traxler, J. (2018). Distance learning: Predictions and possibilities. Science Education,8(1), 35. https://doi.org/10.3390/educsci8010035 